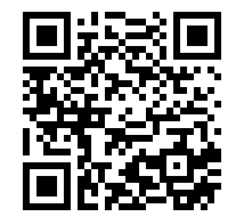

Submitted:

04-11-2020
Journal An-Nafs: Kajian Penelitian Psikologi

http://ejournal.iai-tribakti.ac.id/index.php/psikologi e-ISSN: 2549-6166 p-ISSN: 2528-0600

DOI: $10.33367 /$ psi.v5i2.1382

\title{
AKTUALISASI KOMITMEN BERAGAMA WARIA KOTA KEDIRI
}

\author{
Reza Ahmad Zahid \\ zahidrezaahmad66@gmail.com \\ Institut Agama Islam Tribakti Kediri
}

\begin{abstract}
The existence of transgender in social life still leaves many problems. Negative stigma and discrimination are already firmly attached to them. This problem certainly requires handling so that the negative mindset of transgender women does not only put to something horrible in nature. They also cannot be separated from their natural tendency as religious humans (homo-religious). This study seeks to reveal the religiosity side of transgender women and how they actualize their religious-selves. Because of this reason, the researcher uses the concept of Maslow as self-actualization, then Stark and Glock as religious commitment in the framework of qualitative-phenomenological research. In-depth interviews, observation, and documentation are techniques in extracting data, then analyzed inductively. The results of this study found that the fact, transgender religious behavior fulfills the five dimensions of religion as per the conceptual framework of Stark and Glock as religious commitment. Second, the self-actualization of transgender women in their religious-life also shows that they have an inner need through Nurul Iman jamiyyah. They follow recitation consistently where the senior transgender (adult) has moved to religious maturity that manifested in their daily life by the religious commitment and always follow jamiyyah, and encourage younger transgender women to keep trying to carry out religious-teachings.
\end{abstract}

Keywords: Religious Commitment, Self-actualization, Trasngender Women

\begin{abstract}
Abstrak
Eksistensi waria dalam kehidupan sosial masih menyisakan banyak persoalan. Stigma dan diskriminasi negatif sudah terlanjur melekat kuat pada diri mereka. Persoalan ini tentu memerlukan penanganan agar mindset negatif atas diri waria tidak melulu melekatkannya pada sesuatu yang bersifat negatif. Karena sebagai manusia, mereka juga tidak lepas dari fitrahnya sebagai manusia religius (homo religius). Kajian ini berupaya mengungkap sisi religiusitas waria dan bagaimana mereka mengaktualisasikan diri religiusnya. Untuk itu peneliti menggunakan konsep aktualisasi diri Maslow dan komitmen beragama Stark dan Glock dalam kerangka penelitian kualitatif-fenomenologis. In-depth interview, observasi, dan dokumentasi menjadi teknik dalam penggalian data yang kemudian dianalisis secara induktif. Hasil penelitian ini menemukan bahwa secara faktual perilaku beragama waria memenuhi lima dimensi agama sebagaimana kerangka konseptual komitmen beragama Stark dan Glock. Kedua, aktualisasi diri waria dalam kehidupan beragama juga menunjukkan bahwa sesungguhnya mereka mempunyai kebutuhan batiniah yang disalurkan melalui jamiyyah Nurul Iman dan mengikuti pengajian umum secara konsisten di mana waria senior (dewasa) telah beranjak pada kematangan beragama yang termanifestasikan dalam kehidupan keseharian dan komitmen untuk selalu mengikuti jamiyyah dan mengajak waria yang lebih muda agar tetap berusaha untuk menjalankan ajaran agama.
\end{abstract}

Kata Kunci: Aktualisasi Diri, Komitmen Beragama, Waria 
Reza Ahmad Zahid | Aktualisasi Komitmen Beragama Waria

\section{PENDAHULUAN}

Eksistensi waria mempunyai akar sejarah panjang, misalnya adalah fenomena warok dalam kesenian Reog Ponorogo. Dalam proses pematangan ilmunya itu, warok mempunyai gemblak, yaitu pemuda usia belasan tahun dengan wajah cantik dan berkulit halus yang berfungsi sebagai pelepas hasrat seksualnya. Kondisi ini merupakan jalan bagi Warok karena larangan untuk bergaul dengan perempuan sebelum mencapai tingkat kematangan ilmu. Budaya waria lain tampak pada kesenian ludruk, di mana setiap tokoh perempuan diperankan oleh laki-laki. Begitu juga dengan kesenian gandrung, di mana penarinya adalah laki-laki berusia 10-12 tahun yang berpakaian perempuan. Pada suku Dayak Ngaju di Kalimantan ada pendeta perantara yang mengenakan pakaian lawan jenis. Fenomena serupa juga ada pada suku Bugis di Sulawesi di mana seorang laki-laki ditugaskan menjaga pusaka, berpakaian perempuan dan menjauhi kontak dengan perempuan yang disebut sebagai Bissu (Al-Jum'ah \& Suprihatin, 2019).

Bagi orang Bugis, ada tiga jenis kelamin lain di luar laki-laki (oroane) dan perempuan (makunrai), yaitu calalai (transgender-man), calabai (trangender-woman), dan bissu (androgynus-shaman). Bissu adalah wadam dan orientasi seksualnya adalah homoseks (Pelras, 2006). Selanjutnya adalah calabai yang secara harfiah berarti perempuan palsu (false woman) atau hampir perempuan yaitu laki-laki yang berperilaku seperti perempuan baik dalam berpakaian maupun pekerjaan domestik lainnya. Keberadaan mereka diterima dengan sangat baik oleh masyarakat Bugis dan sebagian besar masyarakat menghormatinya. Calabai juga tidak mempunyai keinginan melakukan operasi kelami karena mereka menikmati kemampuan mereka dalam menggabungkan maskulinitas yang dibawa sejak lahir dan feminitas yang disadari setelah remaja. Meski begitu, mereka harus mematuhi larangan untuk tidak berhubungan seksual dengan perempuan. calabai yang melanggar aturan itu akan dihukum mati dengan cara merebusnya hidup-hidup ke dalam gala atau minyak mendidih (Pelras, 2006). Sedangkan calalai secara etimologis berarti laki-laki palsu (false man) atau hampir laki-laki yaitu perempuan yang berperilaku seperti laki-laki. Jika dikaitkan dengan pembagian gender ini, waria masuk pada kategori calabai (transgender woman/male-transgender) (Davies, 2014, 2018).

Penjelasan di atas menampakkan bahwa eksistensi 'budaya waria' terbilang diterima dalam masyarakatnya karena memang mempunyai akar sejarahnya sendiri dan lahir dari budaya masyarakat setempat. Lalu bagaimana dengan waria saat ini? Istilah waria sendiri bukan produk masyarakat melainkan muncul sebagai istilah yang 
dianggap lebih halus dari istilah lain yang dianggap berkonotasi negatif seperti wadam, banci (akronim Jawa: bandule cilik), bencong, dan seterusnya. Istilah waria merupakan gabungan dari kata wanita dan pria yang perkenalkan pada tahun 1978 untuk mengganti istilah wadam yang kontroversi karena merupakan gabungan dari kata hawa dan adam (Gelarina, 2019). Dalam Kamus Besar Bahasa Indonesia (KBBI) waria diartikan sebagai wanita pria, yaitu pria yang bersifat dan bertingkah laku seperti wanita; pria yang mempunyai perasaan sebagai wanita; wadam (Hasil Pencarian - KBBI Daring, 2019).

Dari definisi ini tampak bahwa waria adalah mereka yang tubuh biologisnya jelas lakilaki, tapi secara psikis mengidentifikasikan diri sebagai perempuan di mana orientasi seksualnya juga mengarah pada sesama jenis. Dengan kata lain, perilaku dan dorongan seksual mereka berbeda dengan kondisi fisiknya. Keberbedaan ini kemudian membuat mereka dianggap menyimpang dari nilai dan tradisi (Koeswinarno, 2004). Penyimpangan perilaku keseharian waria yang mengidentifikasi diri sebagai perempuan dan tampak pada penampilan fisik yang tidak lazim juga melahirkan banyak tekanan sosial dari unit terkecil yaitu keluarga hingga masyarakat (Koeswinarno, 2004; Nadia, 2005). Dari sini tampak bahwa telah terjadi transformasi yang sangat berbeda mengenai fenomena waria dengan berbagai bentuk budaya yang berkaitan dengannya. Di atas semua itu, fenomena waria dengan berbagai dimensi yang mengitarinya telah melahirkan banyak kajian akademik yang jika dipetakan terbentang dari kajian budaya, sosial-keagamaan, kesehatan, HAM, gender, seksualitas, psikologi dan sebagainya.

Dalam buku hidup sebagai waria, Koeswinarno mengeksplorasi ruang sosial waria di Yogyakarta dari unit keluarga hingga masyarakat di mana waria mendapatkan berbagai bentuk penerimaan sosial yang beragam hingga mereka terlempar dari masyarakatnya dan berjuang untuk survive. Kemudian prediksi masa depan waria di mana mereka dihadapkan dengan dua pilihan yaitu menjadi homoseksual atau melakukan operasi kelamin (Koeswinarno, 2004). Kajian serupa lainnya dilakukan oleh Boellstorf yang menjelaskan relasi sosial waria di taman remaja Surabaya. Baginya, TRS merupakan ruang di mana identitas sosial waria diterima karena papan nama toilet di tempat ini bertuliskan wanita dan pria/wanita (Boellstorff, 2004). Selanjutny adalah Widayanti yang mengungkap posisi waria sebagai subaltern dalam struktur sosial masyarakat Yogyakarta berdasarkan identitas transgender. Baginya identitas itu menjadi hal yang rumit dan kompleks karena dalam struktur komunitas waria sendiri terdapat klasifikasi kelas elit waria, lower class (bekerja sebagai pengamen), dan kelas marjinal lainnya (Widayanti, 2009).

Safitri yang mengkaji tentang gerakan kesalehan waria di Pesantren Khusus 
Reza Ahmad Zahid | Aktualisasi Komitmen Beragama Waria

Waria Al-Fattah 'Senin-Kamis' Yogyakarta. Kajiannya mengekplorasi tiga praktik keagamaan, yaitu khotbah progressif, kerudung, dan pilihan terbuka untuk menggunakan sarung atau mukena saat melaksanakan salat (Safitri, 2013). Riset terbaru ditunjukkan Tidey yang memberi informasi berharga mengenai bentuk kesalehan waria. Baginya Ibu Mariyani adalah representasi waria saleh dan berhasil mencapai banyak hal antara lain, mendirikan pesantren khusus waria, menikah dengan laki-laki, mengadopsi seorang putri, KTP perempuan, dan menerima passport yang menetapkannya sebagai perempuan (Tidey, 2019). Selain itu, hasil penelitian Arauf dan Fawaid menginformasikan bahwa waria mempunyai pengalaman keagamaannya sendiri dan mempunyai penafsiran tersendiri mengenai tuhan, ibadah, takdir, dan dosa. Dalam konteks dialog antar agama, waria Yogyakarta tidak hanya memfasilitasi dialog dengan para elit agama, tapi juga mendorong untuk membangun dialog antar agama mereka sendiri (Arauf, 2015; Fawaid, 2017).

Hasil observasi setidaknya ada kurang lebih 100 kaum waria yang menetap di Kota Kediri. Para Waria di kota Kediri terlibat berbagai kegiatan social dan keagamaan di kota Kediri. Mereka menjalankan ajaran agama yang dianutnya. Misalnya Ketua Persatuan Waria eks-Karisidenan Kediri (Perwaka) Kediri ia bersarus Hajah. Artinya ia sebagai penganut agama Islam yang menjalankan ajaran agamanya secara taat.

Tulisan ini hendak memotret tentang sisi religius waria Kota Kediri dan bagaimana mereka mengaktualisasikan kebutuhan beragama di tengah kuat dan beragamnya tekanan sosial yang mereka alami, bahkan hampir meresap pada keseluruhan dimensi kehidupan mereka. Meski begitu, penulis juga perlu menegaskan bahwa kajian ini tidak hendak mengkaji waria dalam perspektif agama. Karena dalam tinjauan agama topik mengenai waria masih bersifat debatable. Nadia mencatat dalam pandangan fikih, waria dapat dikategorikan sebagai khuntha dan mukhannath. Di mana waria khuntha merupakan salah satu varian dari interseks yaitu istilah umum yang digunakan untuk berbagai kondisi di mana seseorang dilahirkan dengan anatomi reproduksi atau seksual yang tampaknya tidak sesuai dengan definisi tipikal perempuan atau laki-laki (Nadia, 2005).

Aktualisasi dalam tulisan ini mengacu pada konsep aktualisasi diri dari Abraham Maslow. Maslow menjelaskan aktualisasi diri sebagai "the full use and exploitation of talents, capacities, potentialities, etc. such people seem to be fulfilling themselves and doing the best that they are capable of doing (Maslow et al., 1987)." Dengan kata lain, aktualisasi diri dipahami sebagai optimalisasi penuh bakat, kapasitas, potensi dan sebagainya yang dilakukan oleh seseorang untuk pemenuhan dirinya dan melakukan yang terbaik yang dapat mereka lakukan. Aktualisasi diri juga menjadi salah satu aspek penting dalam kerangka hierarki kebutuhan 
dasar manusia karena setiap orang harus berkembang sepenuh kemampuannya. Bagi Goble, kebutuhan ini adalah hasrat untuk semakin menjadi diri sepenuh kemampuannya sendiri dan menjadi apa saja menurut kemampuannya (Goble, 2002).

Adapun konsep komitmen beragama dalam tulisan ini mengacu pada penjelasan Stark dan Glock yang merumuskan komitmen beragama ke dalam lima dimensi yang terdiri dari dimensi keyakinan, praktik, pengalaman, pengetahuan, konsekuensi (Stark \& Glock, 1970). Konsep ini menjadi penting untuk digunakan karena pada perkembangannya konsep ini juga digunakan dalam kajian psikologi agama. Paloutzian menjelaskan bahwa “...these dimensions used to be called dimensions of religious commitment. I have changed the wording to religiousness in order to place a more distinct emphasis on the psychological processes that mediate religious belief, behavior, practice, feelings, and effects tha the term commitment might suggest (Paloutzian, 2017)." Dengan begitu, perubahan term dari komitmen menjadi religiustitas dalam penjelasan Paloutzian tetap mengacu pada konseptualisasi komitmen beragam sebagaimana diinisiasi oleh Stark dan Glock. Tulisan ini tetap mengacu pada konsep awal komitmen beragama karena sepenuhnya merujuk banyak rincian dari karya Stark dan Glock dengan mempertautkannya dengan konsep aktualisasi diri Maslow.

\section{METODE}

Penelitian ini menggunakan metode kualitatif. Mempertimbangkan jenis data dan tujuan penelitian, maka dalam penelitian ini peneliti menggunakan paradigm konstruktivisme. Konstruktivisme terwujud dalam studi fenomenologis di mana pembentukan makna mengacu pada pengalaman dan tindakan informan sebagaimana yang mereka alami (Charmaz, 2006). Untuk itu peneliti menggali data melalui jenis penelitian kualitatif yang memuat deskripsi verbal dari situasi kehidupan nyata (Silverman, 2014). Dengan begitu, penulis menggali pandangan dan pemahaman bersama kaum waria dalam kehidupan beragama mereka dan bagaimana mereka mengaktualisasikannya dalam perilaku keseharian dan aktifitas keagamaan melalui jamiyyah Nurul Iman dan pengajian umum lainnya. Termasuk bagaimana mereka memaknai dan menjaga komitmen beragama baik secara individu maupun kolektif. Sumber data penelitian ini berupa transkrip yang dihasilkan dari in-depth interview, diskusi kelompok bersama komunitas waria Kota Kediri, catatan lapangan hasil observasi, dan review dokumen (Simons, 2014; Yin, 2018)

Data pada penelitian ini diklasifikasikan menjadi dua bagian; pertama, data yang merupakan bentuk luar dari ciri-ciri yang teramati. Kedua, data yang merupakan interpretasi yang diberikan oleh informan. Data pertama sangat membantu dalam 
Reza Ahmad Zahid | Aktualisasi Komitmen Beragama Waria

memahami interpretasi yang diberikan oleh informan. Peneliti memilih informan kunci yang terdiri dari, pimpinan, dosen dan mahasiswa. Dengan teknik pengumpulan data wawancara, observasi dan dokumentasi.

Analisis data kualitatif adalah upaya yang dilakukan pada data, termasuk mengorganisir data, mengelompokkannya kedalam unit yang dapat dikelola, mensintesis, menemukan dan menemukan pola, menemukan yang penting dan apa yang akan dipelajari, dan memutuskan apa yang harus dipelajari orang lain tahu. Reduksi data didefinisikan sebagai proses seleksi, dengan penekanan pada penyederhanaan, abstrak dan modifikasi data "mentah" yang dihasilkan dari catatan tertulis di lapangan. Kesimpulan sementara biasanya dapat ditarik oleh para peneliti ketika kegiatan di lapangan masih berlangsung.

\section{PAPARAN HASIL}

Kaum waria Kota Kediri telah mempunyai organisasi resmi yang pewacanaannya telah berlangsung sejak tahun 1980. Proses pendirian organisasi waria Kota Kediri berlangsung sangat lama karena baru berdiri secara resmi pada tahun 2016 dengan nama organisasi Persatuan Waria Kediri (PERWAKA). Sebagai lembaga resmi, perwaka telah mempunyai AD/ART, struktur organisasi, akta notaris no 251, dan program kerja yang fokus pada isu kesehatan, hukum, pemberdayaan, dan keagamaan (Mikha, 2020). Program keagamaan organisasi perwaka ini kemudian menjadi salah satu titik tolak yang menjadi representasi perjalanan batiniah kaum waria Kota Kediri yang terwujud dalam bentuk jamiyyah Nurul Iman. Pada perkembangannya, dari jamiyyah ini terdapat seorang waria yang dapat dikatakan tengah beranjak pada tahap kematangan beragama. Indikasinya tampak pada keaktifannya mengikuti jamiyyah dan penambahan frekuensi mengikuti pengajian umum di luar jamiyyah Nurul Iman. Dia juga sangat konsisten mengajak teman-temannya baik sesama waria dan warga sekitar untuk mengikuti pengajian umum tersebut.

Elemen lain yang menjadi faktor utama menguatnya hasrat pemenuhan kebutuhan batiniah mereka yaitu penerimaan orang tua atas kenyataan bahwa anaknya adalah seorang waria (Monika, 2020). Meskti begitu, aspek ini juga tidak begitu saja menjadi faktor positif karena di luar sana ada banyak waria yang justru mengalami hal berbeda berupa penerimaan negatif orang tua atas kenyataan bahwa anaknya adalah seorang waria. Ketiga faktor ini menunjukkan bahwa sesungguhnya waria mempunyai kesadaran beragama yang teraktualisasikan dengan cara mereka sendiri. Mulai dari pendirian jamiyyah pengajian yang bersifat wajib bagi seluruh anggota perwaka, hingga munculnya kesadaran beragama yang konsisten untuk terus dan saling mengajak agar aktif mengikuti pengajian. Kenyataan ini tentu 
sangat berkaitan dengan aspek psikologis mereka mengenai kesadaran beragama dan bagaimana mereka memanifestasikan kesadaran itu dalam kehidupan keseharian.

\section{PEMBAHASAN}

Komitmen beragama mencakup keterkaitan lima dimensi yang terdiri dari dimensi kepercayaan, praktik, pengetahuan, pengalaman dan konsekuensi (Paloutzian, 2017; Stark \& Glock, 1970). Dimensi kepercayaan/keyakinan terdiri dari harapan-harapan bahwa umat beragama mempunyai pandangan teologis tertentu, yaitu pengakuan atas kebenaran dan prinsip agama (Stark \& Glock, 1970). Lebih lanjut, Stark dan Glock juga menjelaskan bahwa bagi umat Kristiani, kepercayaan itu mewujud dalam bentuk pengakuan pada dunia supernatural, tuhan, juru selamat, dan kehidupan setelah mati. Meski begitu, konseptualisasi Stark dan Glock tetap dapat digunakan dalam kajian ini dengan menyesuaikan konteksnya karena sejak awal Stark dan Glock juga telah menegaskan bahwa "beyond the differences in specific beliefs and practices, there seems to be condiserable consensus among religions on the general ways in which religiousness ought to be manifested. We propose that these general ways provide a set of core dimensions of religiousness (Stark \& Glock, 1970)."

Dari penjelasan ini, maka dimensi kepercayaan waria Kota Kediri dalam kajian ini mengacu pada ajaran Islam tentang konsep iman karena anggota jamiyyah Nurul Iman adalah waria yang beragama Islam. Kepercayaan (iman) dalam ajaran agama Islam yaitu percaya kepada Tuhan, malaikat-malaikat-Nya, Kitab-kitab-Nya, percaya pada takdir ilahi yang baik dan buruk/pertemuan dengan Tuhan (di akhirat), Utusan-Nya, dan hari kebangkitan. Sebagaimana pemahaman umat muslim bahwa agama Islam dirumuskan menurut tiga konsep yaitu, Iman, Islam, dan Ihsan. Islam adalah menyembah Tuhan dan tidak menyekutukannya dengan sesuatu apapun, melaksanakan salat, membayar zakat, berpuasa ramadan, dan menunaikan haji. Sedangkan Ihsan adalah menjadi muslim sempurna yaitu menyembah tuhan seakan-akan melihat-Nya, apabila tidak melihatnya sesungguhnya Dia melihatmu. Ketiga konsep ini membentuk tingkatan di mana Ihsan merupakan tingkat tertinggi, pertengahannya adalah Iman, diikuti Islam. Dengan begitu, orang yang Ihsan (muhsin) adalah seorang mukmin (orang beriman), dan setiap mukmin adalah muslim (orang Islam). Tapi tidak setiap mukmin adalah muhsin, dan tidak setiap muslim adalah mukmin (Izutsu, 1994). Manifestasi dimensi keimanan waria secara konkret akan lebih mudah dilihat melalui praktik keberagamaannya, baik yang dilaksanakan secara kolektif maupun individual. Karena iman adalah keyakinan dasar yang termanifestasikan melalui pelaksanaan rukun Islam secara utuh dan konsisten. 
Sedangkan Ihsan adalah cara tentang bagaimana seharusnya melaksanakan rukun Islam sebagai upaya mendekatkan diri kepada Allah.

Meski begitu, bukan berarti dimensi keyakinan beragama waria tidak bisa dilacak tanpa melalui dimensi praktik keberagamaannya. Karena pada saat tertentu mereka juga memberikan pernyataan-pernyataan yang mengindikasikan dimensi keimanan mereka, terutama berkenaan dengan keyakinan mereka atas keberadaan Allah, takdir, dan kehidupan akhirat. Berkenaan dengan itu Diandra berpendapat bahwa keberadaan jamiyyah Nurul Iman membuat hatinya tenang karena dapat saling bersilaturahim dan beribadah bersama-sama untuk mendekatkan diri pada tuhan karena semua manusia di mata tuhan adalah sama (D. Putri, 2020). Pendapat serupa juga disampaikan Lely, baginya keberadaan jamiyyah ini membuat hatinya menjadi lebih tenang (L. Belezza, 2020). Kedua pernyataan ini menunjukkan bahwa keberadaan jamiyyah Nurul Iman memberikan dampak positif bagi kehidupan batiniah waria. Selain itu, secara implisit pernyataan ini juga memberikan pemahaman bahwa sesungguhnya mereka tidak hanya mengakui keberadaan tuhan tanpa keraguan, melainkan tengah berupaya untuk mendekatkan diri kepada tuhan dengan cara mereka sendiri dan dengan segala keterbatasannya. Ini juga sejalan dengan pernyataan utama yang digunakan Stark dan Glock dalam mengidentifikasi dimensi keyakinan beragama yaitu "I know God really exists and I have no doubt about it (Stark \& Glock, 1970)."

Aspek lain dari dimensi keyakinan beragama dapat dilihat dari pernyataan Monika yang menjelaskan bahwa keberadaan jamiyyah Nurul Iman memberikan kepuasan batin karena dapat melaksanakan ibadah secara bersama-sama dengan waria lain sebagai wujud pemenuhan kebutuhan rohani untuk mengenal Allah dan beribadah kepada-Nya. Melalui jamiyyah itu, dia juga mengharapkan Allah akan membuka pintu hidayah dan pengampunan bagi semua hamba-Nya, dan mati dalam keadaan husnul khatimah (Monika, 2020). Lely juga menyatakan bahwa jamiyyah ini membuatnya merasa lebih dekat dengan Allah dan bersyukur karena ada lebih banyak orang yang mendoakan kedua almarhum orang tuanya (L. Belezza, 2020).

Pernyataan ini tidak hanya berisi penegasan akan keyakinan mereka kepada tuhan. Tapi juga memuat aspek lain yang mengindikasikan keyakinan mereka pada takdir, hari akhir, harapan akan pertolongan tuhan dan aspek sederhana spiritualisme Islam. Selain itu, dimensi keyakinan beragama bagi waria tampak tidak terbatas pada hal-hal yang bersifat keyakinan murni yang diungkapkan secara eksplisit. Bagi Sonia, keberadaan jamiyyah Nurul Iman membuatnya bisa lebih mampu mengubah perilaku karena secara perlahan mengetahui hal-hal baik sesuai ajaran agama dan semoga ada hidayah agar dapat 
menjadi manusia yang lebih baik (Sonia, 2020). Hal serupa juga disampaikan Novanda, baginya keberadaan jamiyyah ini menjadikannya mempunyai keinginan lebih dalam mengubah perilaku untuk mendekatkan diri kepada tuhan dan membuat hatinya lebih tenang dan ingin beribadah lebih baik (Novanda Lorensa, 2020).

Kedua pernyataan ini juga menunjukkan keyakinan mereka akan keberadaan tuhan. Lebih dari itu, mereka juga meyakini bahwa keyakinannya mampu mengubah perilaku menjadi lebih baik secara perlahan. Ini berarti bahwa, dimensi keyakinan (iman) dalam Islam tidak hanya termanifestasikan dalam bentuk ibadah ritual, tapi juga benarbenar mengarahkannya pada perubahan perilaku dalam kehidupan sehari-hari. Dengan begitu, dimensi keyakinan beragama waria mempunyai keterkaitan dengan dimensi praktik beragama. Karena keberadaan jamiyyah Nurul Iman merupakan salah satu gambaran umum dari manifestasi dimensi keyakinan beragama mereka. Sedangkan manifestasi lainnya tampak dari konsistensi mereka mempertahankan jamiyyah tersebut, mengikuti pengajian umum di luar komunitas waria, dan praktik ibadah serta perilaku individual mereka yang perlahan semakin dekat dengan ajaran agama.

Komitmen beragama lainnya adalah dimensi pengalaman agama. Menurut Stark dan Glock, dimensi ini mempertimbangkan fakta bahwa semua agama memiliki harapanharapan tertentu, betapapun tidak tepat untuk menyatakan bahwa orang yang taat beragama pada saat tertentu akan mencapai pengetahuan langsung dan subjektif tentang realitas ultim, yaitu mencapai sesuatu seperti perasaan berhubungan betapapun cepatnya dengan agensi supranatural (Stark \& Glock, 1970). Dengan begitu, dimensi pengalaman agama berkaitan dengan perasaan beragama seseorang dan mempunyai dampak pada dimensi batiniahnya. Fakta di lapangan menunjukkan bahwa aspek ini dapat dilihat terutama pada pengalaman Monika dalam meniti karirnya. Di mana ketika mengalami kesulitan mengenai pekerjaannya kemudian memasrahkan diri pada tuhan dengan tetap berusaha, berdoa, dan sabar. Maka akan ada solusi yang tiba-tiba hadir di luar perkiraannya. Baginya pengalaman itu seringkali terjadi berulang-ulang sehingga memantapkan hatinya untuk selalu bersyukur dalam menghadapi situasi dan permasalahan apapun (Monika, 2020).

Pengalaman serupa juga dialami Sonia yang menceritakan bahwa ketika menghadapi persoalan rumit dan berat dalam hidup dia lebih memilih cara-cara rasional untuk mengatasinya. Saat pikiran dan usaha rasionalnya mengalami kebuntuan dan masalah tidak terselesaikan, dia kemudian memutuskan untuk menyerahkan problem itu pada tuhan dengan mencurahkan hati dan pikirannya melalui doa setelah melaksanakan salat malam. Baginya, setelah melakukan salat malam dan berdoa membuat hatinya dan 
tenang dan entah bagaimana setelah itu jalan untuk menyelesaikan masalah seakan menjadi lebih mudah. Dari sini keyakinannya semakin bertambah dan ungkapan yang selalu dia ingat adalah bahwa tuhan tidak akan pernah menguji hamba di luar batas kemampuannya. Berbagai pengalaman yang dialaminya menjadikannya lebih mantap dan yakin bahwa tuhan hadir pada semua umatnya karena tuhan maha pengasih dan maha penyayang (Sonia, 2020). Fakta lain yang menunjukkan dimensi pengalaman beragama waria adalah pengakuan mereka tentang perasaan dan harapan tentang hadirnya hidayah dan kepuasan batin ketika melaksanakan kegiatan jamiyyah Nurul Iman (L. Belezza, 2020; Monika, 2020; D. Putri, 2020).

Pengalaman-pengalaman tersebut merupakan fenomena pengalaman religius yang dialami waria Kota Kediri. Sebagaimana dapat dilihat pada penjelasan Stark dan Glock tentang pengalaman religius yaitu "as we use the term, all religious experience, from the vaguest to the most frenzied, constitute occasions defined by those undergoing them as an encounter-some sense of contact-between themselves and some supernatural consciousness (Stark \& Glock, 1970)." Lebih lanjut, Stark dan Glock menyebutkan bahwa tipe pengalaman beragama adalah sebuah fenomena progresif yang sistematis. Dengan demikian pengalaman religius yang dialami Soni sebagai mualaf dapat dikategorikan ke dalam tipe pengalaman beragama responsif, yaitu perasaan bahwa ada kehadiran bersama di mana tuhan memperhatikan keberadaaanya sebagai seorang hamba. Sedangkan pengalaman religius waria lain, terkategori ke dalam tipe pengalaman beragama konfirmatif di mana mereka mempunyai perasaan batin tertentu ketika mengikuti kegiatan jamiyyah Nurul Iman seperti perasaan gembira, kepuasan, perasaan nyaman dan tenang berada dalam komunitas jamiyyah dan sebagainya (Stark \& Glock, 1970).

Selanjutnya adalah dimensi pengetahuan dari komitmen beragama. Dimensi ini mengacu pada harapan bahwa orang beragama akan mempunyai informasi minimal tentang prinsip dasar dari iman, ritus, kitab suci dan tradisi keagamaannya. Ini merupakan keharusan bagi mereka yang meyakini dan mempraktikkan (Stark \& Glock, 1970). Dalam Islam, konsep pengetahuan ini terangkum dalam rumusan pengetahuan mengenai akidah, syariat, dan akhlak. Keberadaan jamiyyah Nurul Iman merupakan salah satu sarana pembelajaran agama karena di dalamnya menghadirkan seorang ustadz/kiai untuk memimpin tawasul, tahlil, dan doa bersama. Setelah itu ustadz/kiai yang hadir juga memberikan siraman rohani yang isinya adalah pengetahuan dasar ajaran agama Islam.

Ini sejalan dengan beberapa pendapat waria yang mengatakan bahwa melalui kegiatan rutin jamiyyah Nurul Iman mereka bisa mencari ilmu dan tentang agama Islam, mempunyai pengetahuan yang cukup dalam pelaksanaan ibadah sesuai dengan tuntunan 
agama. Mereka juga mengakui bahwa ibadah mereka belum benar-benar baik secara syariat karena belum bisa membaca al-Quran dengan fasih sesuai kaidah ilmu tajwid dan makharij al-huruf meskipun mereka hafal bacaan tahlil, selawat, dan surat-surat pendek dalam al-Quran. Selain itu, ikhtiar mereka untuk belajar, beribadah, dan menjaga keislamannya adalah dengan mengikuti pengajian umum lain di luar jadwal rutin jamiyyah Nurul Iman. Kesadaran mereka atas keimanan dan pentingnya mempelajari ajaran agama Islam juga mendorong mereka untuk mengadakan lomba mengaji yang dimaksudkan untuk menjaga mereka agar tetap belajar dan termotivasi sehingga ibadah yang mereka lakukan menjadi semakin baik dan sesuai dengan tuntunan agama (N. Lorensa, 2020; Monika, 2020; Sonia, 2020).

Dimensi komitmen beragama terakhir adalah konsekuensi. Dimensi ini berbeda dengan empat dimensi sebelumnya, karena dimensi ini mengacu pada efek dari dimensi kepercayaan, praktik, pengalaman, dan pengetahuan agama seseorang dari hari ke hari (Stark \& Glock, 1970). Di sini, efek dapat disejajarakan dengan amal atau pengamalan ajaran-ajaran agama yang mewujud dalam semua perilaku seseorang dalam kehidupan kesehariannya. Ini berarti efek atau pengamalan ajaran agama termanifestasikan dalam bentuk kesalehan sosial. Kesalehan sosial mencakup semua jenis kebajikan yang ditujukan kepada semua manusia (Sobary, 2007). Lebih jauh, Gus Mus menyatakan bahwa sebenarnya konsep kesalehan dalam Islam hanya satu yaitu kesalehan muttaqi (hamba yang bertakwa), mukmin yang beramal saleh yang sekaligus mencakup kesalehan ritual dan sosial (Bisri, 1994). Berkenaan dengan itu, Fuad menginformasikan bahwa dirinya beberapa kali menyaksikan komunitas waria membagikan takjil pada Ramadan tahun lalu (2019) di perempatan Bandar Kota Kediri (A. J. Fuad, 2020). Hal ini merupakan salah satu bentuk kesalehan sosial yang ditunjukkan waria bagi masyarakat umum. Bentuk lain dari dimensi konsekuensi beragama juga ditunjukkan oleh Sonia yang merupakan tulang punggung keluarga sekaligus menjadi kepala keluarga menggantikan almarhum ayahnya. Sebagai tulang punggung keluarga, Soni bekerja untuk memenuhi kebutuhan hidup keluarganya, yakni ibu dan adiknya.

Manifestasi dimensi konsekuensi beragama juga ditunjukkan Monika yang selalu mengantarkan orang tuanya untuk mengikuti pengajian. Momen ini kemudian memberikan pengaruh rasa beragama yang lebih dalam dirinya sehingga pada saat tertentu berkembang menjadi kebiasaan dan mengajak warga sekitar rumah hingga teman-teman warianya untuk mengikuti salah satu pengajian agama yang terbuka untuk masyarakat umum, yaitu pengajian Gus Lik (Monika, 2020). Gambaran di atas memberikan pemahaman bahwa dimensi konsekuensi beragama dapat mengambil 
banyak bentuk yang mewujud dalam perilaku kesalehan sosial seseorang dalam kehidupan kesehariannya. Lebih lanjut, Stark dan Glock menjelaskan bahwa kelima dimensi komitmen beragama ini senyatanya tidak sepenuhnya independen. Tetapi kelimanya saling berkorelasi secara moderat. Dengan kata lain, kuatnya salah satu dimensi yang dimiliki seseorang tidak berarti kuat pula pada dimensi lainnya sebagaimana penjelasannya bahwa "... that being religious on one dimension does not necessarily imply being religious on another (Stark \& Glock, 1970)." Berkaitan dengan hubungan antara kelima dimensi komitmen beragama, Stark dan Glock menyimpulkannya sebagai sebuah fenomena multidimensi yang dapat diverifikasi secara empiris (Stark \& Glock, 1970).

Jika dikaitkan dengan komponen utama agama Islam, hubungan kelima dimensi komitmen beragama mempunyai kemiripan dengan konsep iman, Islam, dan ihsan. Hubungan ketiga konsep ini seringkali diibaratkan sebagai rumah. Di mana iman sebagai fondasi, Islam sebagai dinding, dan ihsan sebagai atapnya. Ketiga kategori ini bukan dimaksudkan untuk menilai tingkatan orang lain, tapi justru petanda untuk mengambil sikap moderat karena tuhan menciptakan manusia berbeda-beda sesuai maqamnya (Islam, Iman, dan Ihsan Menurut Syekh Zarruq, 2017). Dengan kata lain, umat Islam harus tetap berusaha untuk mencapai tingkatan ihsan tapi tidak memaksakan diri untuk benarbenar mencapai tingkatan tersebut karena setiap orang mempunyai wadah dan maqam masing-masing. Karena itu, kita tidak dapat memungkiri jika dalam kenyataannya ada seorang muslim yang mempunyai pengetahuan mendalam tentang agama tapi perilaku sosialnya justru bertolak belakang dengan ajaran-ajaran agama. Begitu pula sebaliknya, orang yang terbilang sangat saleh secara sosial belum tentu mempunyai pengetahuan yang luas dan mendalam tentang agama. Tapi justru berangkat dari pengamalan ajaran agama yang dia ketahui meski kadarnya sedikit. Kenyataan ini sejalan dengan apa yang telah diungkapkan Stark dan Glock bahwa menjadi religius dalam satu dimensi tidak berarti religius pada dimensi lainnya.

Dengan begitu, apa yang terpaparkan di atas menginformasikan bahwa senyatanya kehidupan beragama waria dapat diletakkan dan memenuhi lima dimensi komitmen beragama. Pertama, dimensi keyakinan/kepercayaan waria tampak dari beberapa pengakuan mereka yang menunjukkan bahwa mereka meyakini keberadaan tuhan tanpa keraguan. Keyakinan itu kemudian berkembang pada harapan-harapan akan hidayah tuhan, rasa syukur, takdir, dan pertolongan di hari akhir. Kedua, dimensi praktik beragama waria termanifestasikan dalam ritual agama yang bersifat publik sebagaimana tampak pada eksistensi jamiyyah Nurul Iman dan konsistensi waria dalam mengikuti jamiyyah tersebut, bahkan beberapa di antara mereka juga mengikuti pengajian umum di 
luar jamiyyah Nurul Iman secara rutin. Selain itu, aspek ketaatan beragama mereka tampak pada pelaksanan ibadah di ruang privat.

Ketiga, dimensi pengalaman beragama. Dimensi ini tampak pada perasaan beragama sebagaimana pengalaman pribadi Monika yang optimis akan ada petunjuk atas suatu cobaan dengan tetap berusaha, tawakal, sabar, dan bersyukur. Pun pengalaman Sonia yang mencurahkan berbagai permasalahan hidup pada tuhan dengan salat malam dan berdoa dengan kepasrahan, perasaan tentang hadirnya hidayah dan kepuasan batin saat beribadah. Keempat, dimensi pengetahuan beragama waria dapat dilihat pada salah satu rangkaian kegiatan jamiyyah Nurul Iman. Di mana di dalamnya terdapat aktifitas belajar ilmu agama yang mereka dapatkan dari ceramah yang disampaikan ustadz/kiai yang hadir pada acara tersebut. Selain itu, mereka juga akan mengadakan lomba mengaji yang dimaksudkan untuk menambah pengetahuan sekaligus sebagai cara untuk motivasi diri agar terus belajar dan semakin baik dalam beribadah sesuai tuntunan agama. Kelima, dimensi konsekuensi (pengamalan) beragama mereka tampak dari beberapa bentuk kesalehan sosial yang mereka tampilkan di ruan publik seperti membagikan takjil dan peran beberapa waria sebagai tulang punggung keluarga, mengajak warga sekitar dan teman-teman warianya untuk mengikuti pengajian umum di luar jadwal jamiyyah Nurul Iman agar mempunyai pengetahuan dan pengamalan agama yang lebih baik.

Dari sini dapat dipahami bahwa model keberagamaan waria mempunyai karakteristik tersendiri yang tidak dapat begitu saja digolongkan ke dalam kategorisasi tertentu. Misalnya konsep Islam KTP atau Islam identitas (Islam nominal) yang digunakan untuk menyebut orang yang mengaku beragama Islam tapi tidak dianggap sebagai muslim taat karena tidak menjalankan ritual agama (Islam KTP Alias Islam Identitas, 2012). Meski begitu, pada saat hari raya mereka juga ikut merayakannya. Konsep inilah yang kemudian disebut Geertz sebagai Islam abangan (Geertz, 1976). Apalagi mengklaim bahwa waria jauh dari kehidupan religius karena kuatnya stigmatisasi yang sudah terlanjur dilekatkan pada mereka. Karena meskipun mereka tereksklusi dari ruang sosial-keagamaan dan mengalami berbagai konflik psikologis. Mereka tetap mempunyai hasrat keagamaan dan mengaktualisasikan kebutuhan batiniah itu dengan cara mereka sendiri. Keberadaan jamiyyah Nurul Iman merupakan wujud aktualisasi diri pemenuhan hasrat keberagamaan mereka untuk tetap melakukan yang terbaik sejauh yang mereka bisa agar fitrah religiusnya berkembang secara optimal menuju insan paripurna sesuai kemampuannya. Beberapa dari mereka juga menyampaikan secara jujur berkenaan dengan pelaksanaan ibadah salat mereka yang belum sempurna baik dilihat dari konsistensi maupun dari sisi keilmuannya, terutama 
berkenaan dengan kefasihan membaca. Meski begitu, mereka tetap terkategori sebagai insan religius karena menjadi religius pada satu dimensi tidak berarti menjadi religius pada dimensi lainnya (Stark \& Glock, 1970). Selain itu, pemilihan istilah jamiyyah juga menjadi wujud akomodasi atas tradisi keagamaan lokal karena di Kediri banyak jamiyyah yang dibentuk oleh masyarakat. Ini tentu berbeda dengan aktualisasi keagamaan waria di daerah lain yang menggunakan istilah pesantren, majelis, atau pengajian khusus waria.

\section{SIMPULAN}

Mengacu pada uraian di atas, maka dapat disimpulkan bahwa aspek keberagamaan waria memenuhi kelima dimensi komitmen beragama yang teraktualisasikan melalui jamiyyah Nurul Iman. Jamiyyah ini juga merupakan bentuk inisiatif waria Kota Kediri dalam mengaktualisasikan kebutuhan batiniah mereka karena mereka mengalami berbagai hambatan psikologis dan sosial untuk bergabung dengan jamiyyah yang ada di lingkungan masyarakat sekitarnya.

\section{DAFTAR PUSTAKA}

Al-Jum'ah, A. N., \& Suprihatin, C. (2019). Mapata's Transformation of Gender Identities in Tiba Sebelum Berangkat. KnE Social Sciences, 94-105-194-105. https://doi.org/10.18502/kss.v3i19.4833

Arauf, M. (2015). Waria's Religion and Interreligious Dialogue: A Case of Waria Community In Kebaya NGO Yogyakarta. Religia, 87-108. https://doi.org/10.28918/religia.v18i1.623

Bagai Bangunan Rumah, Hubungan antara Iman Islam dan Ihsan. (2018, May 21). https://nu.or.id/post/read/90680/bagai-bangunan-rumah-hubungan-antaraiman-islam-dan-ihsan

Belezza, L. (2020, May 16). Interview [Personal communication].

Belezza, L. (2020, June 15). Interview [Personal communication].

Bisri, A. M. (1994). Saleh Ritual, Saleh Sosial. DIVA PRESS.

Boellstorff, T. (2004). Playing Back the Nation: Waria, Indonesian Transvestites. Cultural Anthropology, 19(2), 159-195. https://doi.org/10.1525/can.2004.19.2.159

Charmaz, K. (2006). Constructing Grounded Theory_ A Practical Guide through Qualitative Analysis-SAGE Publications Ltd (2006).pdf. Sage Publication Ltd.

Davies, S. G. (2014). Ben Murtagh, Genders and Sexualities in Indonesian Cinema: Constructing gay, lesbi and waria identities on Screen. Abingdon, Oxon and New York: Routledge, 2013, xiv + 199 pp. [Media Culture and Social Change in Asia series.] ISBN 9780415536318. Price: EUR 90.00 (hardback). Bijdragen Tot de Taal, Land- En Volkenkunde / Journal of the Humanities and Social Sciences of Southeast Asia, 170(4), 594-596. https://doi.org/10.1163/22134379-17004010 
Davies, S. G. (2018). Routledge handbook of contemporary Indonesia (R. W. Hefner \& B. W. Andaya, Eds.). Routledge.

Fawaid, A. (2017). Trans-Religious Identity from the Edge? Promoting Interfaith Dialogue among Transgender Community in Yogyakarta. Al-Albab, 6(1), 103-124. https://doi.org/10.24260/alalbab.v6i1.676

Fuad, A. J. (2020, May 3). (Pengurus LPTNU Jawa Timur, Wakil Rektor II IAIT Kediri). Wawancara. Kediri [Personal communication].

Geertz, C. (1976). The Religion of Java. University of Chicago Press.

Gelarina, D. (2019). Proses Pembentukan Identitas Sosial Waria di Pesantren Waria AlFatah Yogyakarta. Jurnal Kajian Islam Interdisipliner, 1(1). http://ejournal.uinsuka.ac.id/pasca/jkii/article/view/1057

Goble, F. G. (2002). The Third Force, The Psychology of Abraham Maslow (P. Kanisius, Trans.; 11th ed.). Kanisius.

Hasil Pencarian—KBBI Daring. (2019). https://kbbi.kemdikbud.go.id/entri/waria

Islam, Iman, dan Ihsan Menurut Syekh Zarruq. (2017, August 15). https://nu.or.id/post/read/80462/islam-iman-dan-ihsan-menurut-syekh-zarruq

Islam KTP Alias Islam Identitas. (2012, September 11). https://nu.or.id/post/read/39633/islam-ktp-alias-islam-identitas

Izutsu, T. (1994). Konsep Kepercayaan dalam Teologi Islam: Analisis Semantik Iman dan Islam (A. F. Husein, Trans.). Tiara Wacana Yogya.

Koeswinarno. (2004). Hidup sebagai waria. LKiS.

Lorensa, N. (2020, May 16). Interview [Personal communication].

Maslow, A. H., Frager, R., \& Fadiman, J. (1987). Motivation and Personality. Harper and Row.

Mikha. (2020, June 12). Interview [Personal communication].

Monika. (2020, January 25). Interview [Personal communication].

Monika. (2020, May 15). Interview [Personal communication].

Monika. (2020, June 6). Interview [Personal communication].

Nadia, Z. (2005). Waria: Laknat atau kodrat!? Pustaka Marwa.

Paloutzian, R. F. (2017). Invitation to the Psychology of Religion (Third Edition). Guilford Publications.

Pelras, C. (2006). Manusia Bugis (A. R. Abu, Hasriadi, \& N. Sirimorok, Trans.). Nalar [bekerjasama dengan] Forum Jakarta-Paris, Ecole francaise d'Extreme-Orient.

Putri, D. (2020, May 16). Interview [Personal communication].

Safitri, D. M. (2013). The politics of piety in the Pondok Pesantren Khusus Waria Al-Fattah Senin-Kamis Yogyakarta. In J. Burhanuddin \& C. van Dijk (Eds.), Islam in Indonesia: Contrasting images and interpretations. Amsterdam University Press.

Silverman, D. (2014). Interpreting Qualitative Data (5th ed). Sage Publication Ltd.

Simons, H. (2014). The Oxford handbook of qualitative research (P. Leavy, Ed.). Oxford University Press.

Sobary, M. (2007). Kesalehan Sosial. Lkis Pelangi Aksara.

Sonia. (2020, June 15). Interview [Personal communication].

Sonia. (2020, July 2). Interview [Personal communication]. 
Reza Ahmad Zahid | Aktualisasi Komitmen Beragama Waria

Stark, R., \& Glock, C. Y. (1970). American Piety: The Nature of Religious Commitment. University of California Press.

Tidey, S. (2019). Requiem for a Waria. Social Analysis, 63(1), 83-102. https://doi.org/10.3167/sa.2019.630106

Widayanti, T. (2009). Politik subaltern: Pergulatan identitas waria. Research Center for Politics and Government, Jurusan Politik dan Pemerintahan, Universitas Gadjah Mada.

Yin, R. K. (2018). Case study research and applications: Design and methods (Sixth edition). SAGE. 